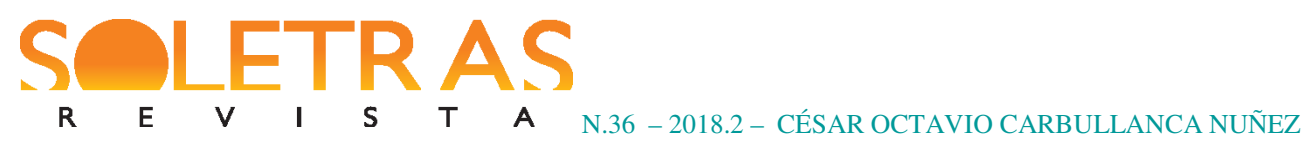

\title{
Mito-poética de Pablo de Rokha
}

\author{
César Octavio Carbullanca Nuñez ${ }^{1}$
}

\begin{abstract}
Resumen: La poesía de Pablo de Rokha está siendo estudiada desde diversos puntos de vista. El artículo pretende pensar qué es un texto religioso a partir de una lectura mítico-poética de la obra del poeta. La poética rokhiana se caracterizará por el concepto de fractura lingüística, sólo comparable con la que realizará Huidobro y Neruda, que nos ayuda a pensar de nuevo al texto religioso.

Palabras claves: Pablo de Rokha. Fractura lingüística. Poesía. Vanguardia.
\end{abstract}

\section{Introducción}

Por un cruel destino, la investigación sobre la vanguardia literaria ha olvidado nombrar la figura del que fue uno de los más grande poetas chilenos. Pablo de Rokha nacido el pueblo costino de Licantén, Curicó, en el año 1894 considerado junto con Gabriela Mistral, Pablo Neruda y Vicente Huidobro como uno de los más grandes poetas de la poesía chilena. El mismo año nace también el poeta Jorge González Bastías en la localidad de infiernillo, Talca.El contexto de la modernidad con sus dos guerras mundiales, con los genocidios y la emergencia del capitalismo mundial que impulsa una sociedad marginadora enfrentan a todos estos poetas y es lo que hace decir a Cristian Enrique Cisternas Cruz:

Lo fragmentario, como etiqueta desprendida de lo antes considerado real referencial, se incrusta en la realidad del esteta-escritor. El extrañamiento de lo que antes aparecía como una pauta dominante para el arte moderno es, digámoslo así, un fragmento disperso que se incrusta en esta realidad y se diluye en su lectura, por lo que el espectador del arte actual del siglo XXI se enfrenta a una realidad de elementos fragmentarios diluida en una ilusoria totalidad (CRUZ, 2013, p. 6).

La poemática como la música, cinemática y la somática forman adjetivos que expresan un conocimiento sobre un fenómeno especifico de la realidad, como puede ser la poesía, la música, el cinema o el cuerpo humano. Así las cosas, el artículo pretende pensar qué es un texto religioso

\footnotetext{
${ }^{1}$ Doctor en Teología Bíblica, Universidad Comillas Madrid (España), postdoctorado en Ciencias de la religión (UMSP). Director Centro de investigaciones de la Religión, Universidad Católica del Maule-Chile. Email:cesarcarbullanca@gmail.com. O presente trabalho foi realizado com apoio da Coordenação de Aperfeiçoamento de Pessoal de Nível Superior - Brasil (CAPES) - Código de Financiamento 001.
} 


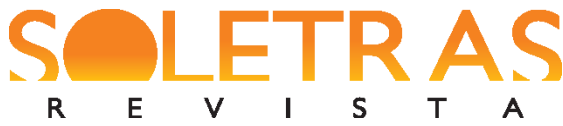

a partir de una lectura mítico-poética de la obra de Pablo de Rokha, poesía que podemos caracterizar constituida por dos elementos fundamentales: primero, la poesía es la expresión literaria del relato mítico de los pueblos; segundo, el lenguaje como inicio y fractura, reflejo de otra no menor, fractura social de que experimenta la cultura.

\section{La transformación del concepto de texto}

a) La comprensión clásica de texto está basada en una comprensión metafísica, esencialista del lenguaje, en el sentido que éste está constituido por las categorías de materia/forma.

b) Deconstrucción del texto. La comprensión clásica del lenguaje hace crisis, entrada la modernidad, con la filosofía nietzscheana: "En otro tiempo, se creía en el alma como se creía en la gramática y en el sujeto gramatical: se decía 'yo' es condición, 'pienso' es predicado y condicionado [...]”(NIETZSCHE,1994, p.80).

Para Nietzsche, la gramática como recurso a leyes del lenguaje esencialistas construye una imagen equivocada de la realidad. La relación entre el "yo" y la gramática citada, expresa que la creencia en un sujeto depende de una determinada estructura sujeto-predicado, estructura substancialista del lenguaje y de la realidad. Además, la alusión al 'pienso luego existo' de la cita expresa que el verbo ser, presupone la idea de la existencia de sustancias independientes. En la cita mencionada, la creencia en el alma, el yo y la gramática son descalificados. Pero al parecer, en la cita, es la gramática la que es responsable de los contenidos pertenecientes a la visión metafísica de la realidad como Dios, yo, historia.

c) Deconstrucción del texto. El sicoanálisis representa una crítica al concepto clásico del texto, pues postula un "yo quebrado", de acuerdo a lo cual, el hombre ya no es dueño de su lenguaje, pues en la misma constitución del yo, este no responde del todo a sus ideas conscientes sino inconsciente, tanto en el sentido freudiano según el cual, el sueño tiene un sentido y este es un sentido que ha sido reprimido por el inconsciente. Por tanto, el concepto de censura está en el origen de la constitución del inconsciente como texto oculto; de este modo la censura es una "barra" de la cual, de un lado aparece el contenido manifiesto del sueño y del otro su contenido latente. Esta trasposición, del contenido manifiesto al latente es lo constitutivo del inconsciente.

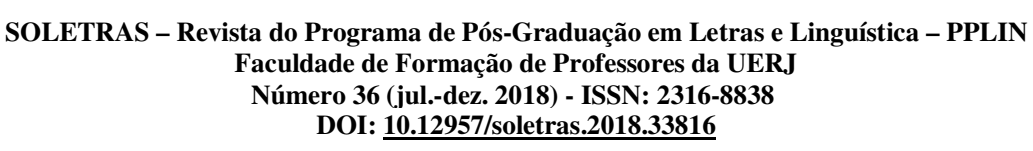



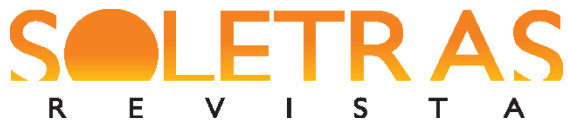

N.36 - 2018.2 - CÉSAR OCTAVIO CARBULLANCA NUÑEZ

Antes de la represión no hay vida inconsciente y precisamente este paso de uno a otro provoca un lenguaje "mixto", "cifrado", el sentido latente pasa disimulado bajo imágenes no evidentes, de modo que la censura no se percate. En la perspectiva junguiana, la censura carece de valor, entre el consciente e inconsciente se produce una analogía no una censura, el inconsciente no representa un carácter conflictivo que se encuentra en Freud sino que este responde a una participación mística con arquetipos universales. Jung en La vida simbólica señala:

[...] los procesos inconscientes no son observables directamente pero aquellos de sus productos que atraviesan el umbral de la conciencias se dividen en dos clases: los pertenecientes al inconsciente personal y los que pertenecen a la humanidad en general, estos contenidos tienen una peculiaridad sobresaliente: su carácter mitológico. [...] y que denomino arquetipos (JUNG, 2009, p. 49).

Y más adelante:

“...el nivel del inconsciente colectivo sólo es posible entenderlos comparándolos con paralelos históricos" (JUNG, 2009, p. 49).

El trabajo sicoanalista de Lacan, pretende ser una interpretación estructuralista del sicoanálisis, tanto en lo que respecta a la comprensión del sueño en su aspecto consciente como a su aspecto inconsciente. Lacandirá en el Seminario 11 "El inconsciente tiene carácter de texto" $(1997,25)$. Tanto en el caso del Jung como Lacan el terapeuta tendrá la labor de reconstruir el texto inconsciente del paciente reduciendo su labor a ser un espejo, sin determinar la interpretación del sueño a sólo aspectos sexuales, como es el caso de la interpretación freudiana.

\begin{tabular}{|l|l|}
\hline Freud & $\begin{array}{l}\text { Conciencia: texto1 /el inconsciente como texto 2: El sueño tiene sentido: } \\
\text { "restos arcaicos" }\end{array}$ \\
\hline Jung & $\begin{array}{l}\text { Conciencia: texto1/el inconsciente como Texto 2: Los arquetipos y los mitos } \\
\text { de la humanidad. El terapeuta calla y el paciente reconstruye el texto } 2\end{array}$ \\
\hline Lacan & $\begin{array}{l}\text { Conciencia: texto } 1 \text { /el inconsciente como Texto 2: estructuralismo del } \\
\text { lenguaje inconsciente. El terapeuta calla y el paciente reconstruye el texto } 2\end{array}$ \\
\hline
\end{tabular}

SOLETRAS - Revista do Programa de Pós-Graduação em Letras e Linguística - PPLIN

Faculdade de Formação de Professores da UERJ

Número 36 (jul.-dez. 2018) - ISSN: 2316-8838

DOI: $\underline{10.12957 / \text { soletras.2018.33816 }}$ 


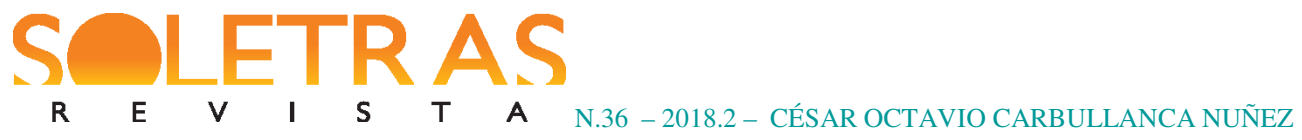

De acuerdo a esto, el inconsciente se comprende como un texto común el cual está constituido por los arquetipos y los mitos de la antigüedad de la humanidad.

d) El concepto lingüístico de texto. Tiene un carácter estructuralista a partir de los trabajos de F. Saussure con su libro póstumo "Introducción a la lingüística". Este libro significa una revolución para la comprensión del lenguaje (habla/lengua), pues introduce el concepto estructural del lenguaje como sistema. La lingüística del siglo XX recibirá un enorme impulso gracias a los siguientes trabajos de Barthes, Benveniste, Genette,...el texto como red de relaciones y el sentido como diferencia entre dos lexemas. Barthes señalaba:

[...] el texto está formado por escrituras múltiples, procedentes de varias culturas y que, unas con otras, establecen un diálogo, una parodia, una constelación, pero existe un lugar en que se recoge toda esa multiplicidad, y ese lugar no es el autor, como hasta hoy se ha dicho, sino el lector: el lector es el espacio mismo en que se inscriben, sin que se pierdan ni una, todas las citas que constituyen una escritura; la unidad del texto no está en su origen, sino en su destino (BARTHES, 1994, p. 71).

Para este autor un texto está en movimiento, viene desde un lugar y se dirige hacia otro, siempre entendido como un "intertexto", es decir, múltiples escrituras que establecen un diálogo o constelación en el texto que se precipitan o tiene su lugar de convergencia en el lector. Éste es espacio en donde se inscriben las citas y alusiones.

\section{La recepción en Latinoamérica y la poesía de Rokha}

Las enumeraciones que realizan los críticos respectos de la vanguardia literaria de la época en Latinoamérica son los poetas César Vallejo, Vicente Huidobro, Oliverio Girondo, Oswald de Andrade, Mário de Andrade, y las primeras etapas de Jorge Luis Borges y de Pablo Neruda. La presencia de Pablo de Rokha es prácticamente ignorada por casi todas las fuentes.

La obra de Rokha es multifacética y extensa, Cristián Geisse Navarro distingue siete etapas de la obra rokhiana (NAVARRO, 2009, p. 180). La primera etapa va de 1916 a 1922 en donde todavía perdura un tono romántico pero anarquista. En 1916 Vicente Huidobro publica su manifiesto del creacionismo. La segunda etapa coincide con la aparición de Los gemidos en 1922

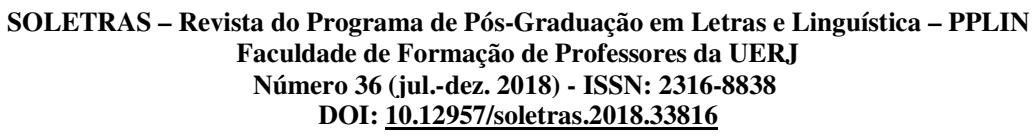




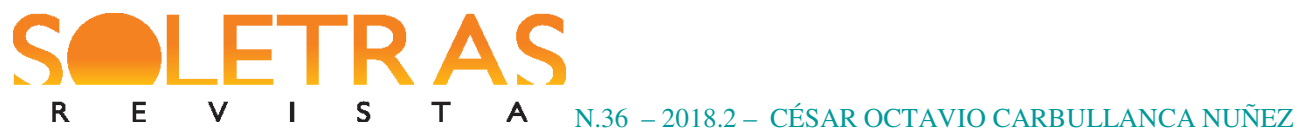

con la propuesta de una fractura lingüística. Responden a los primeros movimientos de la vanguardia estética latinoamericana. Paralelo a Gemidos, en Perú, Cesar Vallejos publica Trilce (1922) que "representa un esfuerzo por liberar a la palabra de las cadenas de la lógica y de los cánones literarios aceptados (FERRARI, 1968, p. 14). Y en 1924 González Bastías publica El poema de las tierras pobres. Oswald de Andrade elabora el Manifiesto Antropófago en 1928. La tercera etapa comprende de 1923 a 1929 y tiene una tendencia hacia el surrealismo latinoamericano con una fuerte presencia de lo nacional-popular. Así se leen los textos de Cosmogonía (1922-1927), U(1925), Satanás (1927) y Escritura de Raimundo Contreras (1929). En la cuarta etapa, 1930 a 1944, domina la épica social y heroica donde sobresale el compromiso social del poeta y en donde se trabaja el proyecto poético desde la asunción de héroes bíblicos como protagonistas del decir poético Jesucristo (1933) y Moisés (1937), también Morfología del espanto (1942) y Gran temperatura (1937). De 1945 a 1954, la épica social americana emerge como forma y teoría artística asociada al estilo del realismo popular constructivo, denominado así por Pablo de Rokha. En este se encuentra el libro Carta magna de América (1949) y La epopeya de las comidas y bebidas del pueblo chileno (1949). La última etapa el poeta busca la totalidad de las representaciones de lo real como Los Arrieros cordilleranos (1957), Acero de invierno (1961), Canto del macho anciano (1961) y Estilo de masas (1965).

\section{El poeta como pequeño dios}

De manera semejante a la comprensión de Huidobro, acerca del poeta como "pequeño dios". Para de Rokha el pronombre yo registra al poeta como un lugar de revelaciones, en quien ocurre las grandes gestas de la humanidad. Ya en un poema temprano de su primera etapa, en la Selva Lirica dice "Yo soy como el fracaso total del mundo" (ROKHA, 1969, p. 9), "Soy el hombre casado, soy el hombre casado que inventó el Matrimonio" (1969, p. 35).En el poema Satanás (1927) que continua el programa rupturista de Gemidos, el poeta se identifica con Satanás y dice:

YO EXISTO,

iah!,

SOLETRAS - Revista do Programa de Pós-Graduação em Letras e Linguística - PPLIN

Faculdade de Formação de Professores da UERJ

Número 36 (jul.-dez. 2018) - ISSN: 2316-8838

DOI: $\underline{\text { 10.12957/soletras.2018.33816 }}$ 


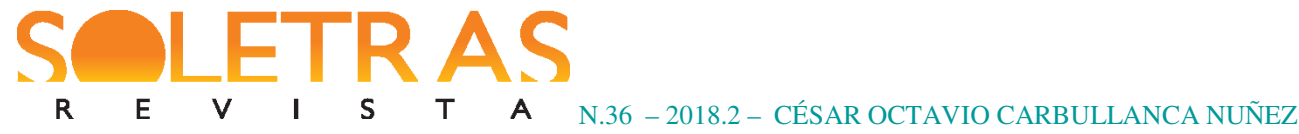

YO EXISTO sobre el dia corriendo,

AQUI,

pregunto mi dirección a las alondras del infinito mis infinito,

CANTO, CANTO, CANTO

(ROKHA, 1969, p. 41).

El yo de Rokha se refiere al Canto como lugar axial en su obra. El empleo de la Mayúscula tanto para "yo existo" como "Aquí" como en "Canto, canto, canto" se repite y pretende decir algo más que la palabra normal en minúscula. La ruptura que representa tan uso, contiene un sentido pragmático del lenguaje que identifica la emergencia del yo y su canto más allá del sistema de simbólico de las modernidades convencionales. Podríamos decir, es un yo rupturista del sistema lingüístico del mundo. En Los Gemidos (1922), el poema La balada de Pablo de Rokha describe su persona:

Yo canto, canto sin querer, necesariamente, irremediablemente, fatalmente, al azar de los sucesos, como quien. come, bebe o anda y porque si; moriría si no cantase, moriría si no cantase; el acontecimiento floreal del poema estimula mis nervios sonantes, no puedo hablar, entono, pienso en canciones, no puedo hablar, no puedo hablar; las ruidosas, trascendentales epopeyas me definen e ignora el sentido de mi flauta; aprendí a cantar siendo nebulosa, odio, odio las utilitarias labores, zafias, cuotidianas, prosaicas y amo la ociosidad ilustre de lo bello; cantar, cantar, cantar... -he ahí lo único que sabes, Pablo de Rokha (ROKHA, 1922, p. 9).

El canto está en las antípodas del capitalista utilitarista, la labor prosaica que inunda la ciudad de Talca, Santiago de Chile. En Epitalamios declara nuevamente que el yo poético se vuelve canción "Todo yo, todo yo me hice canciones en su actitud ancha; las palabras suyas son órganos míos". Rokha no cree en Dios, más aún tiene expresiones irreverentes y burlescas para la fe en un Dios trascendente. Se trata de una expresión sublimada el Canto como el hombre que deviene el canto del pueblo, estético.

\section{El poeta multifacético}

Pablo de Rokha es uno de aquellos poetas que se han querido desmarcarse del logos Occidental, al asumir una visión nietzscheana de arte (CERDA, 2008, p. 145; BARROS, 2016,

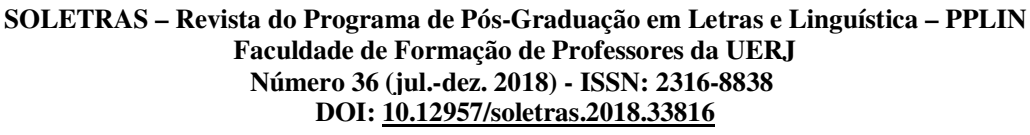




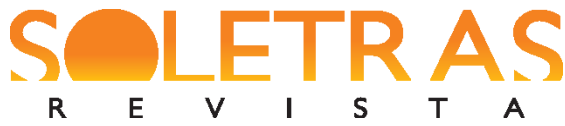

pp. 143-156). Como es sabido, la comprensión de este filósofo pretende en su segunda etapa, una renuncia no sólo de una racionalidad científica sino además de toda la racionalidad occidental. Tomando esto en consideración, para de Rokha, el arte se caracteriza por ser enigmático, político, vivo e imaginario:

a) Enigmático. Rokha afirma que el arte es "enigmático y problemático es el arte porque enigmático y problemático es el hombre". En Ecuación (1929) escribe "al poema, como al candado, es menester echarle llave".

b) Es político: "Todo lo artístico es político, pero los grandes artistas son líderes artísticos, no líderes políticos, precisamente porque todo lo artístico es político, pero es político porque es artístico, no es artístico porque es político" (NÓMEZ, 2013,p. 247). Curet señala "proponen una forma de vivir poéticamente un mundo dominado por lo político" (CURET, 2015, p. 109). De Rokha al igual que el modernismo brasileño de Oswald de Andrade "Nunca fuimos catequizados", reconoce en el pueblo chileno un "nosotros" propio con su propia epopeya.

c) Organismo vivo: señala en Ecuación "que el poema devenga ser, acción, voluntad, organismo...", como un organismo vivo señala "que constituya, que determine, que establezca su atmosfera...dejad al animal nuevo la ley que él cree...que él cree, que él es...”. Dice también “ojalá el poema se ría solo, sin recuerdos, ojala sin instintos". En 17 dice "que se ría solo y llore solo como la más morena de las colegialas, sacándose la camisa". La vida del poema aclara en Ecuación número 7, radica no en su volumen, no en lo aritmético, no en su rima, en la ley...más bien el de Rokha llama: "incendiad el poema, degollad el poema” el porvenir del canto radica "que giren todos los elementos épicos alrededor de su eje astronómico", este tema Rokha lo repetirá una serie de veces. "eje astronómico", "gravitación lírica" "que deviene lo absoluto, límite del límite” (NÓMEZ, 2013, p. 82).

d) Meta-conceptual. El poema tiene como registro lo imaginario, pues requiere ir más allá del concepto por eso señala "Que nunca el canto se parezca a nada, ni a un hombre, ni a un alma, ni a un canto" (NÓMEZ, 2013, p. 81). El poema es un "edificio de imágenes que son productos químicamente puros del no consciente" Un poema es un poema no porque esté escrito en verso, un poema es un poema porque está escrito en un leguaje de imágenes y metáforas, que es el lenguaje del arte y existe la imagen plástica y la imagen arquitectónica o musical" "todo el arte es uno y trabaja la misma materia imaginística” (NÓMEZ, 2013, p. 248).

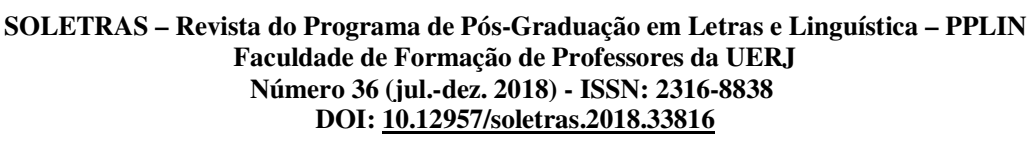




\section{La poesía como inicio y fractura}

José Miguel Curet Arana sostiene que Rokha realiza la ruptura con modelos pre-existentes se hace en Los gemidos (ARANA, 2006, p. 109). Esta ruptura con los cánones literarios y lingüísticos que encontramos en Vallejos y Huidobro, se corresponde con una visión crítica de la modernidad que ha fragmentado el proceso social latinoamericano y chileno, es en opinión de Nómez "constituye un extenso canto en prosa poética cuya temática y composición expresa la crisis nacional y la fragmentación del proceso social" (NÓMEZ, 1987, p. 12). En el caso de Vallejos, vemos en Trilce en el poema IX, el poeta transgrede las reglas gramáticas como las hará Huidobro y de Rokha: "Vuscovolvvver de golpe el golpe[....] Busco vol ver de golpe el golpe. [...] Fallo bolver de golpe el golpe" (FERRARI, 1968).Se trata a juicio de este autor de una escritura fragmentada, el yo poético es grandilocuente y megalómano, el yo poético inventa su propio lenguaje para expresarse.

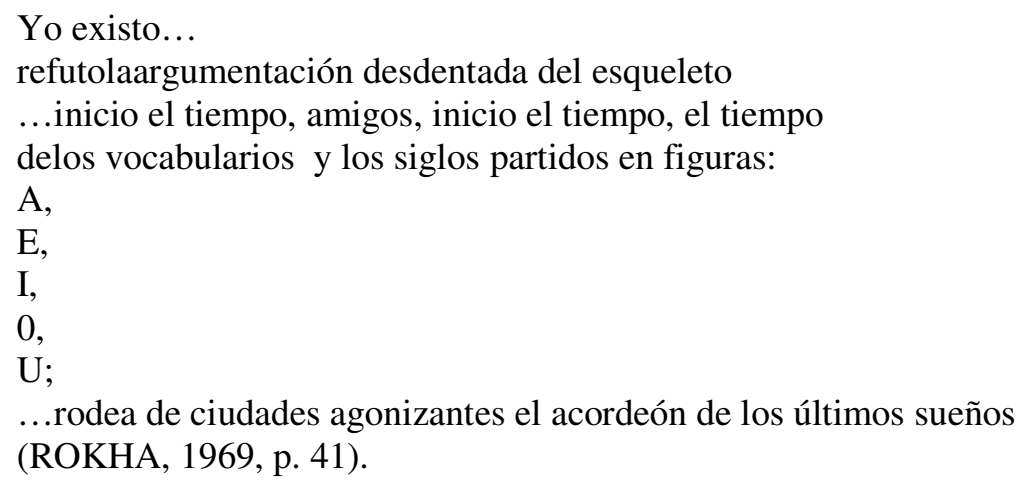

En opinión de José Miguel Curet Arana

[...] su adolorida voz se alza en medio de un mundo caótico, dividido, contradictorio e inconexo, igual que su composición y lectura que es precisamente inconexa, contradictoria, dividida y marcada por los fenómenos que atestigua y les otorga su significado y su relevancia en el proceso de escritura (ARANA, p. 110). 


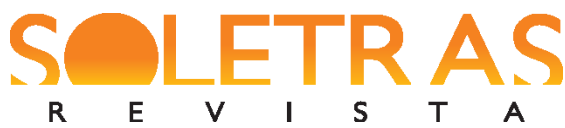

N.36 - 2018.2 - CÉSAR OCTAVIO CARBULLANCA NUÑEZ

Como ya hemos mencionado, el uso de la mayúscula y la forma gráfica vertical o discontinua de la poesía de Rokha, muestra el carácter transgresor de la vocación poética. El yo del poeta y la poesía inicia los tiempos y los vocabularios. Este inicio representa el carácter irreverente de Rokha, quien pretende una fractura con lenguaje consuetudinario del statu quo. En el libro de los Gemidos (1922) se aprecia el concepto de fractura nietzscheano según el cual la racionalidad es deformadora, mentirosa, estética:

[...] yo canto, canto sin querer, irremediablemente, al azar de los sucesos", y también: "las trascendentales me definen e ignoro el sentido de mi flauta, aprendí a cantar siendo nebulosa, cruzo las épocas cantando como un gran sueño deforme mi verdad es la verdadera verdad (ROKHA, 1922, p. 13).

Y más adelante muestra que su yo poético es el precipitado del yo nacional: "mis cantares absurdos, modestísimos suman el pensamiento; todo el pensamiento de la raza y la voz del instante soy un país hecho poeta por la gracia de Dios".

En opinión de Naín Nómez:

En Los gemidos, la ruptura y la reestructuración de las significaciones se da a través de una búsqueda de la totalidad de lo fragmentado, mostrando lo uno y lo otro. El sujeto aparece como el ordenador de un mundo compartimentado en la política, la economía, la religión, la sexualidad, la vida cotidiana, la represión social. La obra literaria establece relaciones de ruptura, haciendo de la propia escritura una interpretación personal de la vida como totalidad no fragmentada (NÓMEZ, 1994, pp. 10-11).

En Satanás que en opinión de Cureu continua la obra de Gemidos "se redefine la frontera entre el bien y el mal haciéndola ambigua y sin razón de ser" (ARANA, p. 92). La repetición de frases y palabras remite como en Huidobro, también a una fractura. En Gemidos, en el epitafio de su esposa declama:

Winett: ya habrá llovido mucho, mucho, mucho .........entonces, entonces no seremos nada, nada, nada, nada, nada masque dos sueños helados; el mismo túmulo cobijará tus virtudes, mis huesos, mis huesos; y cuando TU ACTITUD me golpee la puerta del sepulcro llamándome: Pablo.. . MI Pablo.. . no te oiré!..., no te oiré no te oiré, no te oiré, no te oiré, no te oiré, pues, aunque vecinos, toda la eternidad, toda la eternidad, toda la eternidad, toda la eternidad entre nosotros ha de haber caído muerta; otros hombres, otros hombres, otras mujeres,

SOLETRAS - Revista do Programa de Pós-Graduação em Letras e Linguística - PPLIN

Faculdade de Formação de Professores da UERJ

Número 36 (jul.-dez. 2018) - ISSN: 2316-8838

DOI: $\underline{\text { 10.12957/soletras.2018.33816 }}$ 

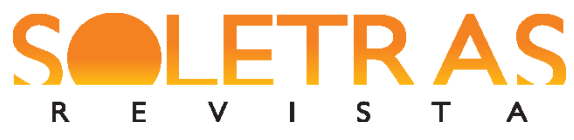

otros hombres y otras mujeres poblarán la provincia del mundo y el pueblo en que nacimos...y todo, todo, todo, todo, todo, todo, todo será polvo.

$[\ldots]$

Y solo mi voz, mi voz, mi grande voz oscura, ira cantando, alegre y nueva, alegre y nueva aún... (ROKHA, 1922, pp. 117-118).

El recurso a las repeticiones crea una imagen no solo un significado abstracto: de feísmo, de fatalismo emotivo, podríamos decir que ante la repetición las palabras se siente de otra manera. La palabra repetida reconstruye la escena emotiva de la muerte del ser amado. Esta repetición que también encontramos en Huidobro, refleja la influencia nietzcheana en la poesía de Rokha y que es acreditada por diversos autores, si esto es así la fractura está entendida en términos radicales, como fin de la metafísica occidental que se arrastra a partir del pensamiento socrático.

\section{La poesía y la lucha social}

La tercera etapa de Pablo de Rokha hay dos poemas a personajes bíblicos Jesucristo y Moisés, en ellos la poesía de Rokha se vuelve profético-política; se trata nuevamente de la ruptura del poeta ensimismado, del poeta como individuo al margen de la lucha social. Esta etapa de la poesía de Rokha está muy en consonancia con la militancia política de otros poetas surrealistas en Europa, y de poetas latinoamericanos como Neruda. La poesía de otro maulino posee este mismo tenor, Jorge González Bastías en su poema de las tierras pobres escribe:

La queja sube al cielo en el vaho doliente de la tierra, en el aroma tenue de las flores, en las tristes pupilas que se ausentan,..

Una miseria nueva prendió en las hondonadas y en los cerros, arrasó los sembrados, y los rebaños y los huertos.

El pobre se hizo miserable, el miserable, bandolero! 

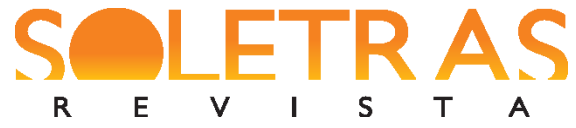

\section{N.36 - 2018.2 - CÉSAR OCTAVIO CARBULLANCA NUÑEZ}

Rokha se caracteriza en el contexto de la vanguardia latinoamericana más que Vallejo, más que Huidobro por el papel asignado al pueblo. Éste es el sujeto de la epopeya histórica. El pueblo chileno es descrito de mil maneras, sus sufrimientos, sus comidas, sus bebidas, sus hombres, sus mujeres, los trabajos, sus juegos. Toda la vida del pueblo es materia poética.

Vemos esto ya en el poema La epopeya de las comidas y bebidas del pueblo Chileno, y en la Carta Magna del continente y también en el poema Los arrieros cordilleranos, el poeta escribe:

Canto en verso indo-latino

la épica americana.

...hambrientos, desarrapados,

Ellos son el pueblo chileno

Y de lo bueno lo bueno,

Grito y médula sumados;

Los mártires olvidados

Y los frutos del país...

Y aprieta la miseria

Dan lección de hombría enorme,

A una sociedad deforme

Corroída por la histeria

...lleno de próceres muertos el país se desintegra...

el porvenir trae un eco de osamentas

y el provinciano anda a tientas

entre el vivir y el morir

(NÓMEZ, 2013, p. 162).

También en "La republica asesinada":

Canto mi llanto nacional sangrando entre soldados sin pabellón,

contra las médulas pisoteadas y comparo el futuro a una máquina de oro en las tinieblas.

Mi nombre es Chile y mi apellido lo infinito.

Y en

Es tan dificil saber en qui consiste la vida, que nadie entiende a nadie, y no sabemos por qui el vecino horriblemente hundido en la inutilia1 funeral de la existencia desventurada, 


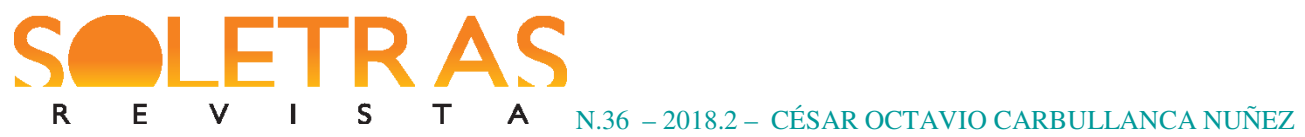

como 1os naufragos a las astillas del navio: que naidenrempuie a naiden por elante e naiden porque naidencompriendió renuncapaonde rumbea la vida e naiden", decia el roto Machuca (1969, p. 294)

En el Moisés (1937), Rokha relata la epopeya del pueblo con largas frases con pocos puntos, y muchas comas, sin sujetos aparentes "el varón nacional emergía", "como la voz del clan místico...del país ensangrentado" describe a Dios en relación al pueblo: "Jehová, su propio enigma, lo llamo y lo hecho hacia su destino" (ARANA, 2015, p. 92). En su estilo Rokha describe una de las plagas de Egipto:

Y todo el polvo de la tierra se volvió piojos, piojos de piojos, y piojos de piojos de piojos, y piojos de piojos de piojos de piojos, grandes como el hambre del pueblo, piojos de abajo y de ahora y de adentro, horrorosamente, llenos de materia oscura, piojos de manta de vagabundo, o de héroe o de presidiario, piojos de dios, tremendos, piojos.

A diferencia de poemas anteriores, acá no se subraya la idea de una fractura del lenguaje, más bien cabe mencionar que la idea que rige es la de reinterpretar el mito del Éxodo en clave modernista. La lucha política del pueblo chileno se hace eco de esta epopeya que narra la liberación del pueblo judío. Antes de la teología de la liberación tenemos en Jorge González Bastías, y Pablo de Rokha dos poetas que recurren a motivos bíblicos para interpretar el presente oprimido del pueblo chileno. Esta intertextualidad del poema es clara, y el relato del Éxodo se trasparente en el poema, dejando ver el vocabulario marxista de "proletario", "camarada". El Moisés del poema es llamado "profeta", "camarada". Él es uno del pueblo, el enemigo es la “metafísica del desierto", "ÉL” con mayúscula, los opresores.

\section{La intuición poética}

En el escrito postulo la Intuición Poética escribe Rokha "la intuición poética de los pueblos de todos los pueblos del mundo crea la leyenda, que es la interpretación artística popular de la realidad" (NÓMEZ, 2013, p. 247). El papel liberador de la intuición mítico poética es

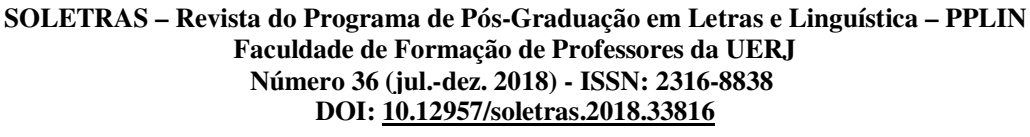




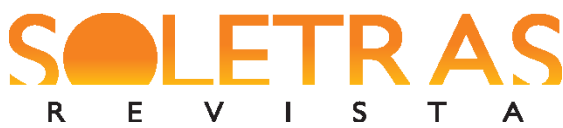

\section{N.36 - 2018.2 - CÉSAR OCTAVIO CARBULLANCA NUÑEZ}

subrayado por Rokha reiteradamente: "El pueblo, al engendrar lo mítico-legendario no se evade, no produce enajenación y evasión de la realidad, sino que al contrario 'lo sublima, es decir, la recrea, la supera con ella adentro" (NÓMEZ, 2013, p. 247).

Y en otra parte: “...la poesía aporta a la búsqueda de la verdad en cuanto "verdad estética, intuitivamente, no como sentido conceptual” (NÓMEZ, 2013, p. 247). No es la realidad pero “contiene la realidad" (NÓMEZ, 2013, p. 247). Este papel mítico del pueblo en la creación artística es descrito en otra parte señalando que "el pueblo crea al gran artista retratándose en el, que es su idioma y su vocabulario, retratándose y expresándose, de lo que se desprende el rol inmenso de la belleza" (NÓMEZ, p. 248). Él dirá de sí mismo en Estilo de Masa (1965): "Yo construyo la "épica social americana como mítico social del realismo insurgente y combatiente de los inmensos pueblos americanos" (NÓMEZ, 2013, p. 247).

El yo poético está al servicio de épica socio-americana, y el lenguaje poético proviene del subsuelo social, es "reflejo vital del pueblo" proviene de las costumbres, las visiones poéticas emergen de las cosas, la misma naturaleza posee una 'dinámica colosal' con sus equivalencias y contradicciones, en el Poema Tonada a la posada de don Lucho Contardo:

[...] extraigo mi idioma universal (como quien cosecha trigo o porotos), del subsuelo social y el reflejo vital de mi patria, y hago el lenguaje internacional, De todos los pueblos de todos los tiempos,

Estrujo la costumbre a la manera de los limones, y escribo como testigo y juez y reo del pueblo y tribunal supremo del pueblo del pueblo,

Las visiones que emergen de las cosas, sobrepujando las cosas y su ímpetu,

La dinámica colosal de la naturaleza,

El sistema de las equivalencias y la contradicción dialéctica, la energética que acumulamos, subquimérica, o cantando o llorando,

Aquella problemática inmensa, y soy roto chileno que empuña la pluma como un corvo (ROKHA, 1969, p. 294).

En forma de un programa estético señala Pablo de Rokha Canto del Macho anciano establece la vinculación entre mito popular y poesía:

Esculpí el mito del mundo en las metáforas,

La imagen de los explotados y los azotados de mi época

$y$ di vocabulario al ser corriente sometido al infinito,

...la poesía se sublimó en expresión de todos los pueblos,

El anónimo y el decrepito y el expósito hablaron su lengua,

$Y$ emergió desde las bases la mitología general de Chile

SOLETRAS - Revista do Programa de Pós-Graduação em Letras e Linguística - PPLIN

Faculdade de Formação de Professores da UERJ

Número 36 (jul.-dez. 2018) - ISSN: 2316-8838

DOI: $\underline{\text { 10.12957/soletras.2018.33816 }}$ 

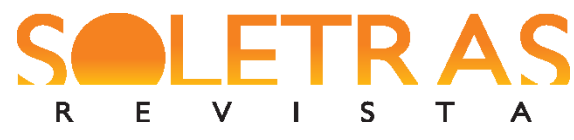

N.36 - 2018.2 - CÉSAR OCTAVIO CARBULLANCA NUÑEZ

y el dolor colonial enarbolando su ametralladora.

(ROKHA, 1949,p. 33).

Es importante atender en este poema a la categoría del mito: el poeta sostiene que el pueblo de "los explotados y azotados de mi época" posee un logos que es "mítico", aun más ¿qué es eso de "la mitología general de Chile"? es importante atender a esta cuestión; el poeta postula que los pueblos, los sectores populares poseen un logos mítico mediante el cual el "anónimo y el decrépito y el expósito" expresan su propia cosmovisión. Recordemos que lo característico de la época moderna ha sido reducir el pensamiento mítico al individuo, pero sí los pueblos como lo señala de Rokha tienen una "mitología" de tal manera que la poesía deviene su hija ilustrada.

\section{Últimas palabras}

La poesía de huaso licantenino de Rokha posee una originalidad que lo relaciona con otras poéticas contemporáneas, pero éste va más allá que la propuesta poética de vanguardia en varios puntos que resultan sumamente relevantes para los estudios de religión y literatura. En primer lugar, la relación entre mito y poesía desarrollado por de Rokha mediada por la categoría de sujeto sigue colocando a los estudios sobre literatura y religión con el desafío que volver a pensar qué es un texto literario y qué es un texto religioso, ¿qué es lo que hace un texto religioso llegue a ser tal? ¿No será posible que la movilización de las energías, las creencias de un pueblo no llevan en un momento dado de manera eventual y transformar textos poéticos, literarios en textos en los cuales la gesta épica de los pueblos se identifica? En segundo lugar, el uso radical de la fractura derrokhiana muestra una tarea por estudiar, nosotros sólo hemos mostrado algunos aspectos. La importancia de dicho concepto es de relevancia para diversas áreas de estudio como son los estudios teológicos, religiosos y literarios y que caracteriza no sólo a la modernidad sino al estudio de la literatura universal. La fractura lingüística no sólo representa un nuevo lenguaje que se opone y critica al lenguaje en uso sino que lleva consigo un nuevo concepto de texto, el cual es construido por el poeta a partir del silencio del pueblo.

\section{Referencias}

SOLETRAS - Revista do Programa de Pós-Graduação em Letras e Linguística - PPLIN

Faculdade de Formação de Professores da UERJ

Número 36 (jul.-dez. 2018) - ISSN: 2316-8838

DOI: $\underline{\text { 10.12957/soletras.2018.33816 }}$ 


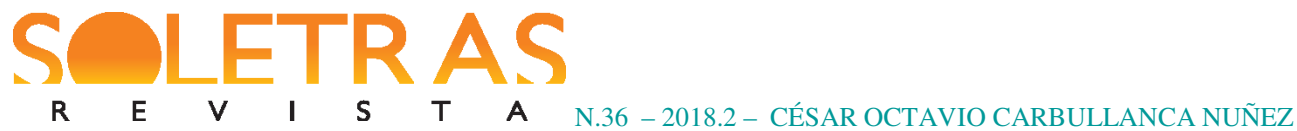

ACEVEDO, Pablo. El embrión cósmico de Pablo de Rokha. Anales de Literatura Hispanoamericana, n. 34, 2005, p. 159-178.

ARANA, José Miguel Curet. Pablo de Rokha: vanguardia y geocrítica. La poesía de U (1926) y Carta magna de América (1949). Tese de Doutorado, Universidad de Salamanca, 2015.

BARROS CRUZ, María José, Imaginarios etílicos en Pablo Neruda y Pablo de Rokha: hacia una poética de la embriaguez. APHA, n, 43, 2016, p. 143-156.

BARTHES, Roland. El susurro del lenguaje. Más allá de la palabra y la escritura. Buenos Aires: Editorial Paidos, 1994.

BASTÍAS, Jorge González. El poema de las tierras pobres. Santiago: Soc. Imp. y Lit. Universo, 1924.

CERDA, Juan Antonio Requena. Idea de poesía en Pablo de Rokha en el periodo 1922 a 1929.In:RevistaF@ro, n. 7, 2008. Disponível em: <http://web.upla.cl/revistafaro/03_estudios/07_ requena.htm>. Acesso em 13 abr. 2018.

CRUZ, Cristian Enrique Cisternas.La escritura fragmentaria. Delirios de Alejandro Jodorowsky. Dissertação de Mestrado, Chile, Universidad de Concepción, 2013.

FERRARI, Américo. César Vallejos. Obras completas. Ed. Digital Moro, 1968. Disponível em: http://web.upla.cl/revistafaro/03_estudios/07_requena.htm. Acesso em 13 abr. 2018.

JUNG, Carl. La vida simbólica. Madrid: Trotta, 2009.

LACAN, Jacques. Seminário 11. Los cuatro conceptos fundamentales del psicianálisis. Buenos Aires: Paidós, 1997.

LÓPEZ, Asunción Rangel. El canto: el dios profundo de Pablo de Rokha. In: Káñina, Rev. Artes y Letras. Costa Rica, n. 38, 2014,p. 43-52.

NAVARRO, Cristián Geisser. Algunos aspectos del posicionamiento de Pablo de Rokha en el campo literario chileno.In: Analecta, Ano III, n. 3, 2009.Disponível em: http://www.academia.edu/1354733/APUNTES SOBRE UN ARTE DISENSUAL EN VALP ARAÍSO. Acessoem 13 abr. 2018.

NIETZSCHE, F. Asi habló Zaratustra, Madrid: Alianza, 2004.

NIETZSCHE, F. La gaya Ciencia, Buenos Aires: Poseidon, 1947.

NIETZSCHE, F. Más allá del bien y del mal. 13. ed. Madrid: Alianza, 1994.

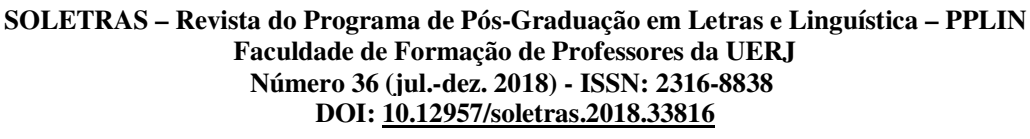



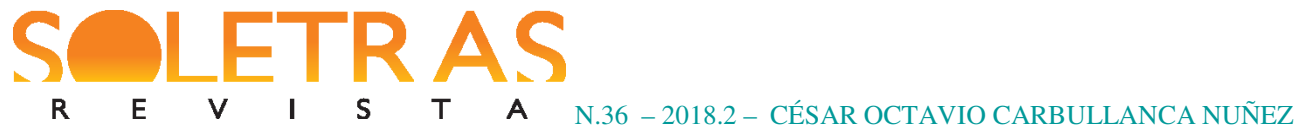

NÓMEZ, Naín. Invitación al lector. In: ROKHA, Pablode. Los gemidos. Santiago: LOM Ediciones, 1994.

NÓMEZ, Naín.Escrito en Rokha.Antologia poética de Pablo de Rokha. Talca: Ed. Universidad de Talca, 2013.

ROKHA, Pablo de. Los Gemidos. Santiago:Condor, 1922.

Mis grandes poemas. Antología.Santiago: Nacimento, 1969.

. Nueva antología. Santiago: Sin Fronteras, 1987.

. Escritura de Raimundo Contreras. 2. ed. Editorial Cuarto Propio: Santiago, 2001.

La epopeya de las comidas y bebidas. Canto del macho anciano. Santiago: Ed.

Universitaria, 1949.

SAN MARTín, Magda Francisca Bustos. Poética del sufrimiento en la obra de Pablo de Rokha. Memoria. Universidad del Bio-Bio, Concepcíon, 2015.

SAUSSURE, F. Curso de Lingüística General. Buenos Aires: Editorial Losada, 1945.

\section{Mito-poematica de Pablo de Rokha}

Resumo: A poesia de Pablo de Rokha está sendo estudada de diferentes pontos de vista. O artigo pretende refletir sobre o que é um texto religioso baseado em uma leitura mítico-poética da obra do poeta. A poesia rokhiana será caracterizada pelo conceito de fratura lingüística, só comparável com aquela realizada por Huidobro e Neruda, que nos ajuda a pensar de novo ao texto religioso.

Palavras-chave: Pablo de Rokha. Fratura linguística. Poesia. Vanguarda.

Recebido em: 21 de abril de 2018.

Aceito em: 06 de julho de 2018. 